\title{
Structures from Powders: Polynuclear Hg(II) Complexes Containing the Flexible Bisimidazolylmethane Ligand.
}

\begin{tabular}{|c|c|}
\hline Journal: & Inorganic Chemistry \\
\hline Manuscript ID: & ic-2009-00320h.R1 \\
\hline Manuscript Type: & Article \\
\hline $\begin{array}{r}\text { Date Submitted by the } \\
\text { Author: }\end{array}$ & 19-Mar-2009 \\
\hline Complete List of Authors: & $\begin{array}{l}\text { Masciocchi, Norberto; Università degli Studi dell'Insubria, } \\
\text { Dipartimento di Scienze Chimiche e Ambientali } \\
\text { Figini Albisetti, Alessandro; University of Milan, Chimica Strutturale } \\
\text { e Stereochimica Inorganica } \\
\text { Sironi, Angelo; Universita' di Milano, DCSSI } \\
\text { Pettinari, Claudio; University of Camerino, Scienze Chimiche } \\
\text { Di Nicola, Corrado; University of Camerino, Scienze Chimiche } \\
\text { Pettinari, Riccardo; University of Camerino, Scienze Chimiche }\end{array}$ \\
\hline
\end{tabular}

\section{s scholarONE \\ Manuscript Central}




\begin{abstract}
Several polynuclear $\mathrm{Hg}(\mathrm{II})$ complexes containing the flexible ditopic bisimidazolylmethane ligand $\left(\mathrm{C}_{7} \mathrm{H}_{8} \mathrm{~N}_{4}\right.$, bim) have been prepared by reaction of equimolar quantities of mercury salts (acetate, cyanide, thiocyanate, chloride and iodide) in $\mathrm{EtOH}$ or acetonitrile solution. Their crystal and molecular structures were retrieved from laboratory powder diffraction data, and their thermal properties fully characterized, including the determination of the thermal expansion coefficients and the related strain tensor using thermodiffractometric methods. $\left[\mathrm{Hg}(\mathrm{bim})\left(\mathrm{CH}_{3} \mathrm{COO}\right)_{2}\right]_{2}$ consists of cyclic dimers with chelating acetates, while the $\left[\mathrm{Hg}(\mathrm{bim}) \mathrm{X}_{2}\right]_{\mathrm{n}}$ species $(\mathrm{X}=\mathrm{Cl}, \mathrm{CN}, \mathrm{SCN}$ and $\mathrm{I})$ are one-dimensional polymers, with dangling $\mathrm{X}$ groups. A further complex of nominal $\mathrm{Hg}_{2}(\mathrm{bim}) \mathrm{Cl}_{2}$ formulation was also prepared, but the complexity and non-ideality of its powder diffraction traces prevented the determination of its main structural features.
\end{abstract}

Keywords: $\mathrm{Hg}(\mathrm{II})$ complexes, nitrogen ligands, X-ray powder diffraction, thermal strain tensor. 


\section{Introduction}

In the last years we have been interested in the coordination chemistry of polydentate ligands possessing multiple donor sites. Starting from simple heteroaromatic anions, such as pyrazolate, ${ }^{1}$ imidazolate $^{2}$ and pyrimidinolate, ${ }^{3}$ we further increased the complexity of the polytopic N-ligands employed in the formation of monomeric, oligomeric and polymeric species. For example, our recent results of substituted triazines, ${ }^{4-5}$, scorpionates ${ }^{6}$ and substituted heterocycles ${ }^{7}$ has allowed us to prepare and characterize a number of functional species, ranging from catalytically active (soluble) oligomers, ${ }^{8}$ to extended solids capable of molecular sensing and recognition. ${ }^{9}$ Recently, when the isolated material was not available as single crystals of suitable quality, the structural characterization has been performed employing state-of-the-art powder diffraction methods coupled with ${ }^{13} \mathrm{C}$ CP-MAS NMR spectroscopy. ${ }^{10}$

In the last years, bisimidazolylmethane (bim), ${ }^{11}$ a ligand employed for the investigation of the biological allosteric effect in zinc-gable porphyrin complexes ${ }^{12}$ and as an artificial receptor capable of binding anionic guests, ${ }^{13}$ has been successfully used as a flexible divergent donor to construct coordination polymeric materials. Several $\mathrm{Ag},{ }^{14} \mathrm{Mn},{ }^{15} \mathrm{Cd},{ }^{16} \mathrm{Zn},{ }^{17} \mathrm{Co}^{18}$ and $\mathrm{Li},{ }^{19}$ monodimensional zig-zag chains or two-dimensional grid network structures have been recently reported and some of them have been described as promising candidates for application in electronic devices and catalysis. To date, no mercury derivatives of this ligand are known, notwithstanding a very recent report on the use of imidazolyl-based ligands for the preparation of luminescent polymeric mercury complexes, in which weak interactions play a significant role in the formation of supramolecular architectures. $^{20}$

In particular, several oligomeric or polymeric species containing the neutral bisimidazolylmethane ligand (bim, see Scheme I) have been recently prepared, and studied by a combination of less conventional structural methods, ${ }^{21}$; these studies included a detailed analysis of the stereochemical preference about the two rotationally flexible $\mathrm{CH}_{2}-\mathrm{N}$ bonds, and the thermal characterization of the anisotropic thermal expansion coefficients and of the thermal strain tensor derived there from.

We have now prepared several third row transition metal derivatives ( $\mathrm{Hg}$ (II) complexes), which were studied by X-ray powder diffraction methods and thermodiffractometry, adding a partial structural interpretation of the observed thermally induced deformations. Mercury compounds are extremely toxic, and it might appear somewhat unusual for researchers to systematically pursue their preparation, isolation and full characterization. However, we found it very useful to determine the stereochemical preferences of $\mathrm{Hg}$ (II)-based bim-containing polymers, after we successfully addressed the nature, reactivity and structure of several zinc and cadmium analogues in a very 


\section{Experimental Section}

Materials and Methods. All reagents were obtained from commercial sources and were used without further purification. Solvents were distilled using the standard methods. The sample for microanalysis was dried in vacuum to constant weight (293 K, ca. 0.1 Torr). Elemental analysis (C, H, N, S) were performed with a Fisons Instruments 1108 CHNS-O Elemental analyser. IR spectra were recorded from 4000 to $600 \mathrm{~cm}^{-1}$ using a Perkin-Elmer Spectrum 100. Melting points (m.p.) were undertaken with a SMP3 Stuart scientific instrument and in a capillary apparatus and were uncorrected. Perkin Elmer STA-6000 model thermogravimetric analyzer was used for determination of the thermal stabilities of mercury complexes. Samples weighing 5-10 mg were heated in dynamic nitrogen atmosphere from 20 to $800^{\circ} \mathrm{C}$ at a heating rate of $5^{\circ} \mathrm{C} \mathrm{min}^{-1}$. The ligand bim has been prepared by standard literature methods. ${ }^{22,23,24}$

$\left[\mathrm{Hg}(\boldsymbol{b i m})\left(\mathrm{CH}_{3} \mathrm{COO}\right)_{2}\right]_{2}$, 1. An ethanol $(20 \mathrm{~mL})$ solution of bis(imidazolyl)methane $(0.296 \mathrm{~g}, 2.0$ mmol) was added to an ethanol $(40 \mathrm{ml})$ solution of mercury(II) acetate, $\mathrm{Hg}(\mathrm{OAc})_{2}(0.636 \mathrm{~g}, 2$ mmol). A colorless precipitate formed. The suspension was stirred for $6 \mathrm{~h}$, then filtered off and the colorless residue was washed by a mixture of ethanol/diethyl ether and identified as $\mathbf{1}(0.887 \mathrm{~g}, 95 \%$ yield). El. Anal. Calc. for $\mathrm{C}_{14} \mathrm{H}_{14} \mathrm{HgN}_{4} \mathrm{O}_{4}$ : C, 28.30; $\mathrm{H}=3.02 ; \mathrm{N}, 12.00$. Found: C, 27.99; H, 2.93; N, 11.80. IR (KBr, cm $\left.{ }^{-1}\right):$ 3114(m), 3024(w), 2935(m), 1559(s), 1523(m), 1504(m), 1391vs(vs), 1332m(vs), 1285(m), 1229(s), 1092(m), 1034(w), 1017(w), 944(w), 931(w), 859(w), 786(w), 764(m), 709(m) 666(s), 653(s), 618(m), 390(w).

$\left[\mathbf{H g}(\boldsymbol{b i m})(\mathrm{SCN})_{2}\right]_{n}, 2$. An ethanol $(20 \mathrm{~mL})$ solution of bis(imidazolyl)methane $(0.178 \mathrm{~g}, 1.2 \mathrm{mmol})$ was added to an ethanol $(40 \mathrm{~mL})$ suspension of mercury(II) thiocyanate, $\mathrm{Hg}(\mathrm{SCN})_{2}(0.316 \mathrm{~g}, 1.0$ mmol). A colorless precipitate immediately formed. The suspension was stirred for $6 \mathrm{~h}$, then filtered 
off and the colorless residue was washed by ethanol:diethyl ether 1:1 (5 mL) and identified as 2 (0.348 g, 75\% yield). El. Anal. Calc. for $\mathrm{C}_{9} \mathrm{H}_{8} \mathrm{HgN}_{6} \mathrm{~S}_{2}: \mathrm{C}, 23.25 ; \mathrm{H}=1.73 ; \mathrm{N}, 18.08 ; \mathrm{S}=13.79$. Found: C, 23.58; H, 1.69; N, 17.73; S = 13.93\%. IR ( $\left.\mathrm{cm}^{-1}\right): 3121(\mathrm{~m}), 3025(\mathrm{w}), 2113(\mathrm{~s}), 1521(\mathrm{~m})$, 1499(m), 1441(w), 1419(w), 1386(m), 1229(s), 1188(w), 1117(m), 1085(s), 1025(w), 928(m), 847(m), 833(m), 750(s), 702(s). ${ }^{1} \mathrm{H}$ NMR (DMSO-d 6 , 293K): $\delta, 6.35$ (s, 2H, CH CHim $_{2}$ ), 7.03 (pd, 2H, $\left.\mathrm{CH}_{\text {Bim }}\right), 7.57$ (pt, 2H, $\left.\mathrm{CH}_{\text {Bim }}\right), 8.18\left(\mathrm{pd}, 2 \mathrm{H}, \mathrm{CH}_{\text {Bim }}\right)$.

$\left[\mathrm{Hg}(\boldsymbol{b i m})(\mathrm{CN})_{2}\right]_{n}, 3$. An acetonitrile $(20 \mathrm{~mL})$ solution of bis(imidazolyl)methane $(0.075 \mathrm{~g}, 0.5$ $\mathrm{mmol})$ was added to an acetonitrile $(40 \mathrm{~mL})$ solution of mercury(II) cyanide, $\mathrm{Hg}(\mathrm{CN})_{2}(0.126 \mathrm{~g}, 0.5$ $\mathrm{mmol}$ ). A colorless precipitate immediately formed. The suspension was stirred for $4 \mathrm{~h}$, then filtered off and the colorless residue was washed by acetonitrile $(5 \mathrm{~mL})$ and identified as $4(0.150 \mathrm{~g}, 75 \%$ yield). Mp. $257^{\circ} \mathrm{C}$ dec. El. Anal. Calc. for $\mathrm{C}_{9} \mathrm{H}_{8} \mathrm{HgN}_{6}$ : C, 26.97; $\mathrm{H}=2.01 ; \mathrm{N}, 20.97$. Found: C, 27.25; H, 1.95; N, 20.60\%. IR ( $\left.\mathrm{cm}^{-1}\right): 3142(\mathrm{w}), 3117(\mathrm{w}), 3024(\mathrm{w}), 1521(\mathrm{~m}), 1492(\mathrm{~m}), 1392(\mathrm{~m})$, 1367(w), 1355(w), 1287(m), 1227(s), 1112(m), 1081(s), 1029(w), 921(m), 845(m), 771(m), 747(s), 708(s), 655(s). ${ }^{1} \mathrm{H}$ NMR (DMSO-d 6 , 293K): $\delta, 6.33$ (s, 2H, $\mathrm{CH}_{2 \mathrm{Bim}}$ ), 7.00 (pd, 2H, CH Bim $_{\text {) }} 7.52$ (pt, 2H, $\left.\mathrm{CH}_{\mathrm{Bim}}\right), 8.16$ (pd, 2H, $\left.\mathrm{CH}_{\text {Bim }}\right)$.

$\left[\mathbf{H g}(\boldsymbol{b i m}) \boldsymbol{I}_{2}\right]_{\boldsymbol{n}}$, 4. An acetonitrile $(20 \mathrm{~mL})$ solution of bis(imidazolyl)methane $(0.075 \mathrm{~g}, 0.5 \mathrm{mmol})$ was added to an acetonitrile $(40 \mathrm{~mL})$ solution of mercury(II) iodide, $\mathrm{HgI}_{2}(0.224 \mathrm{~g}, 0.5 \mathrm{mmol})$. The red solution turned colorless in few minutes and then a colorless precipitate formed. The suspension was stirred for $6 \mathrm{~h}$, then filtered off and the colorless residue was washed by acetonitrile $(5 \mathrm{~mL})$ and identified as 3 (0.280 g, $93 \%$ yield). Mp. $206-208^{\circ} \mathrm{C}$ dec. El. Anal. Calc. for $\mathrm{C}_{7} \mathrm{H}_{8} \mathrm{I}_{2} \mathrm{HgN}_{4}$ : C, 13.95; $\mathrm{H}=1.34 ; \mathrm{N}, 9.30$. Found: C, 14.23; H, 1.28; N, 9.02\%. IR ( $\left.\mathrm{cm}^{-1}\right): 3140(\mathrm{w}), 3115(\mathrm{w}), 3103(\mathrm{w})$, 3005(w), 1596(w br), 1521(m), 1504(m), 1486(m), 1386(m), 1280(m), 1232(m), 1111(m), 1093(s), 1084(s), 1022(m), 928(m), 8448m), 837(m), 771(m), 753(s), 738(s), 710(s), 652(s). ${ }^{1} \mathrm{H}$ NMR (DMSO-d 6 , 293K): $\delta, 6.26$ (s, 2H, $\mathrm{CH}_{2 \mathrm{Bim}}$ ), 6.92 (pd, 2H, $\mathrm{CH}_{\text {Bim }}$ ), 7.47 (pt, 2H, $\mathrm{CH}_{\text {Bim }}$ ), 8.05 (pd, $\left.2 \mathrm{H}, \mathrm{C} H_{\text {Bim }}\right)$.

$\left[\mathbf{H g}(\text { bim }) \mathrm{Cl}_{2}\right]_{n}$, 5. An acetonitrile $(20 \mathrm{~mL})$ solution of bis(imidazolyl)methane $(0.178 \mathrm{~g}, 1.2 \mathrm{mmol})$ was added to an acetonitrile $(40 \mathrm{ml})$ suspension of mercury(II) chloride, $\mathrm{HgCl}_{2}(0.340 \mathrm{~g}, 1.1 \mathrm{mmol})$. A colorless precipitate formed. The suspension was stirred for $6 \mathrm{~h}$, then filtered off and the colorless residue was washed by acetonitrile $(10 \mathrm{~mL})$ and identified as $5(0.369 \mathrm{~g}, 80 \%$ yield $)$. El. Anal. Calc. for $\mathrm{C}_{7} \mathrm{H}_{8} \mathrm{HgN}_{4} \mathrm{Cl}_{2}$ : C, 20.03; $\mathrm{H}=1.92 ; \mathrm{N}, 13.35$. Found: C, 19.93; H, 1.87; N, 12.95. IR $\left(\mathrm{cm}^{-1}\right)$ : 3117(m), 3011(w), 1499(br), 1388(m), 1354(w), 1276(m), 1227(s), 1196(w), 1188(w), 1109(m), 1084(s), 1032(w), 1022(w), 943(w), 936(w), 928(w), 852(m), 844(m), 832(m), 782(m), 761(s), 750(s), 707(s), 654(s). ${ }^{1} \mathrm{H}$ NMR (DMSO-d 6 , 293K): $\delta, 6.28$ (s, 2H, $\mathrm{CH}_{2 \mathrm{Bim}}$ ), 6.94 (pd, 2H, CH $H_{\text {Bim }}$ ), 7.48 (pt, 2H, CH $H_{\text {Bim }}$ ), 8.07 (pd, 2H, $\mathrm{CH}_{\text {Bim }}$ ). 
$\left[\mathrm{Hg}_{2}(\boldsymbol{b i m}) \mathrm{Cl}_{2}\right]_{\boldsymbol{x}}$, 6. An acetonitrile $(20 \mathrm{~mL})$ solution of bis(imidazolyl)methane (0.178 g, $\left.1.2 \mathrm{mmol}\right)$ was added to an acetonitrile $(40 \mathrm{ml})$ suspension of mercury(I) chloride, $\mathrm{Hg}_{2} \mathrm{Cl}_{2}(0.236 \mathrm{~g}, 0.5 \mathrm{mmol})$. A colorless precipitate formed. The suspension was stirred for $1 \mathrm{~h}$, then filtered off and the colorless residue was washed by acetonitrile $(10 \mathrm{~mL})$ and identified as $6(0.280 \mathrm{~g}, 90 \%$ yield $)$. El. Anal. Calc. for $\mathrm{C}_{7} \mathrm{H}_{8} \mathrm{Hg}_{2} \mathrm{~N}_{4} \mathrm{Cl}_{2}$ : C, 13.56; $\mathrm{H}=1.30 ; \mathrm{N}, 9.03$. Found: C, 13.86; H, 1.30; N, 8.87. IR $\left(\mathrm{cm}^{-1}\right)$ : 3143(w), 3117(m), 3017(w), 1526(m), 1508(m), 1492(m), 1427(w), 1394(m), 1353(w), 1285(m), 1229(s), 1196(m), 1115(m), 1097(m), 1086(s), 1035(w), 1025(w), 935(m), 850(m), 845(m), 760(s), 744(s), 708(s).

[Hg(bim) $\left.\mathrm{Cl}_{2}\right]_{x} \cdot x \mathrm{DMSO}$, 7. Reaction between 5 and two equivalents of DMSO in $\mathrm{CH}_{2} \mathrm{Cl}_{2}$, yields a powder that has been identified as 5.DMSO. El. Anal. Calc. for $\mathrm{C}_{9} \mathrm{H}_{14} \mathrm{Cl}_{2} \mathrm{HgN}_{4} \mathrm{OS}$ : C, 21.72; $\mathrm{H}$, 2.83; N, 11.26; Found: C, 21.77; H, 3.02; N, 11.55. IR $\left(\mathrm{cm}^{-1}\right)$ : 3118(w), 2995(w) 2912(w)), 1530(w), 1507(w) 1309(w) 1290(w), 1234(m), 1092(br), 1043(s), 1017(s), 951(m), 931(m), 896(w), 852(w), 765(m), 746(m), 697(m) 667(m).

X-ray Powder Diffraction Analysis: Powdered, microcrystalline samples of 1-5 were gently ground in an agate mortar, then deposited in the hollow of an aluminium sample holder (equipped with a zero-background plate). Diffraction data were collected with overnight scans (16 h long) in the 5$105^{\circ} 2 \theta$ range on a Bruker AXS D8 Advance diffractometer, equipped with a linear positionsensitive Lynxeye detector, primary beam Soller slits, and Ni-filtered $\mathrm{Cu}-\mathrm{K} \alpha$ radiation $(\lambda=1.5418$ $\AA$ ); sampling interval (in continuous mode): $\Delta 2 \theta=0,02^{\circ}$. divergence slit: $1.0^{\circ}$; goniometer raidus $300 \mathrm{~mm}$; generator setting: $40 \mathrm{kV}, 40 \mathrm{~mA}$. Standard peak search, followed by indexing with TOPAS $^{25}$ allowed the detection of the approximate unit cell parameters later improved by LeBail refinements. Indexing figures of merit (M/Gof, falling in the $23-69$ value range) can be found in Table 1. Space group determinations, performed using systematic extinction conditions, in conventional mode as well using a structureless full pattern profile match, indicated, as probable space groups (later confirmed by successful structure solutions and refinements) $P 2_{1} / n$ for $\mathbf{1}, P 2_{1} / c$ for $\mathbf{2}, C 2 / c$ for $\mathbf{3},{ }^{26}$ and $P 2_{1} / m$ for $\mathbf{4}$ and $\mathbf{5}$. Structure solutions was performed (by the simulated annealing technique, as implemented in TOPAS, using for bim a partially flexible rigid, idealized model, ${ }^{27}$ independent metal and/or, where pertinent, halide ions, as well as rigid acetate, $\mathrm{Hg}$ (cyanide) $)_{2}$ or thyocyanide groups. The final refinements were carried out by the Rietveld method, maintaining the rigid bodies described above and allowing the refinement of the torsion angles of the methylene-heterocyclic rings linkage. Peak shapes were defined by the Fundamental Parameters Approach implemented in TOPAS, while crystal size effect was modelled by a Lorentzian broadening. The background contribution to the total scattering was modelled by 
Chebyshev's polynomials with 2 to 8 coefficients, depending of the nature of the trace below Bragg peaks. One, refinable isotropic thermal parameter was assigned to the metal atom, augmented by 2.0 $\AA^{2}$ for lighter atoms. A preferred orientation correction was introduced (in the March-Dollase formulation) along the [111] direction for compound 3. The final Rietveld refinement plots are shown in Figure 1. Table 1 contains a summary of crystal data and data collection parameters and structural analysis.

Thermodiffractometric experiments were performed in air from $25^{\circ} \mathrm{C}$ up to the decomposition temperatures using a custom-made sample heater, assembled by Officina Elettrotecnica di Tenno, Ponte Arche, Italy. Diffractograms at different temperatures (in $20^{\circ} \mathrm{C}$ steps) were recorded typically in the range $8-35^{\circ} 2 \theta$. Linear, parametric ${ }^{28}$ Le Bail refinements, eventually afforded the 'best' set of cell parameters at the different temperatures. Linear thermal expansion coefficients were then derived from $(1 / \mathbf{x})(\partial \mathbf{x} / \partial \mathrm{T}) v s$. T plots ( $\mathbf{x}$ being either a lattice parameter or the cell volume). Later, for each compound, we selected the cell data at two well separated temperatures (typically, $25^{\circ} \mathrm{C}$ and the last useful point before decomposition, falling in the $125-245^{\circ} \mathrm{C}$ range) and computed the thermal strain tensor, its eigenvalues and eigenvectors, using a locally developed program based on Ohashi's algorithm. ${ }^{29}$ Thermal strain tensors were visualised with WinTensor, ${ }^{30}$ which produces a VRML three-dimensional surface to be displayed, together with the (properly oriented) whole crystal structure, with the CORTONA VRML client Crystal structures VRML pictures produced with Accelrys DS Visualizer 2.0.

\section{Results and Discussion}

\section{Synthesis and Spectroscopy.}

Complexes of $\mathbf{1}$ and $\mathbf{2}$ were synthesised by mixing equimolar quantity of the mercury salts and bim in ethanol at room temperature, whereas 3-5 were isolated as colorless precipitates from MeCN solutions. All complexes are stable at room temperature and highly insoluble in water and in alcoholic and chlorinated solvents. Compound 6 has been obtained by reacting $\mathrm{Hg}_{2} \mathrm{Cl}_{2}$ with excess bim. Derivatives 2-5 were found to be moderately soluble in DMSO, their oligomeric or polymeric nature being likely modified by DMSO solvation and/or coordination: for example, from a DMSO solution of $\mathbf{5},\left[\mathrm{HgCl}_{2}(\mathrm{DMSO})_{2}\right]^{31}$ was always recovered in quantitative yield; at variance, when an equimolar quantity of DMSO was added to a $\mathrm{CH}_{3} \mathrm{OH}$ suspension of $\mathbf{5}$, the coordination polymer $\mathbf{5}$ is recovered unaltered. Finally, when an equivalent of $\mathbf{5}$ was reacted with two equivalents of DMSO, a new species was obtained, identified by elemental analysis and IR as 5DMSO, a compound analogous to the already known $\left[\mathrm{HgI}_{2}(\mathrm{dpb})(\mathrm{DMSO}]_{\mathrm{n}}\right.$ polymer $(\mathrm{dpb}=2,3$-di-(4-pyridyl)-2,3- 
butanediol). ${ }^{32}$ Differently, compound $\mathbf{1}$ is poorly soluble also in DMSO, in contrast with its molecular (dimeric) structure (vide infra). However, when a DMSO suspension of $\mathbf{1}$ was heated at $90^{\circ} \mathrm{C}$ for $30 \mathrm{~min}$, displacement of the bim ligand from the mercury coordination sphere is observed. Our observations suggest that, at room temperature, only excess DMSO is able to disrupt the polymeric structure of $\mathbf{2 - 5}$, interacting with the tetrahedral mercury centers and breaking the $\mathrm{Hg}-\mathrm{N}$ coordination bonds, whereas it was unable to interact with the dinuclear species $\mathbf{1}$ in which the mercury ions is in a approximately coordinatively-saturated pseudo-octahedral environment. Apparently, bim possesses a greater coordinating ability toward $\mathrm{Hg}^{2+}$ with respect to DMSO. Accordingly, when an equimolar quantity of bim is added to a $\mathrm{MeOH}$ solution of $\left[\mathrm{HgCl}_{2}\left(\mathrm{DMSO}_{2}\right]\right.$ immediate precipitation of 5 is observed.

The NMR data in DMSO of the compounds 2-5 are not significantly different from that of the free ligand bim, suggesting that the polynuclear chains are completely destroyed in DMSO solution. Interestingly, the ${ }^{1} \mathrm{H}$ NMR spectrum of a mixture containing equimolar quantity of DMSO and of species $5\left(\mathrm{CDCl}_{3}\right.$ solution) exhibits signals different from those found for the free bim in the same solvent, suggesting that in these conditions not all $\mathrm{Hg}-\mathrm{N}$ bonds are lost. As anticipated, when a large excess of DMSO- $\mathrm{d}_{6}$ is added to the $\mathrm{CDCl}_{3}$ solution of $\mathbf{5}$, then formation of the $\mathrm{Hg}(\mathrm{DMSO})_{2} \mathrm{Cl}_{2}$ species is observed. In addition, the ${ }^{1} \mathrm{H}$ NMR spectrum of a suspension of $\mathbf{1}$ in DMSO- $\mathrm{d}_{6}$, recorded at $90^{\circ} \mathrm{C}$, shows only signals of free bim, further supporting our hypothesis.

It is worth to note that, differently from that observed in the case of the already reported zinc and cadmium derivatives, ${ }^{21 \mathrm{~b}}$ when $\mathrm{Hg}$ (II) ions are used in the starting materials, only species showing the $1: 1 \mathrm{HgX}_{2}$ :bim stoichiometry were isolated, independently on the metal-to-ligand ratio employed. As expected, $\mathbf{6}$ shows a different stoichiometry, being the only species containing $\mathrm{Hg}$ in a lower oxidation state.

The IR spectra of these solid species typically show several bands usually associated with the organic ligand: signals of weak and medium intensity at ca. $3000 \mathrm{~cm}^{-1}$ (C-H stretching modes) and other more intense bands between 1600 and $1500 \mathrm{~cm}^{-1}$ (typical of ring breathing) are present, shifted to lower frequency by about $15-20 \mathrm{~cm}^{-1}$ from the reference free ligand values. ${ }^{22-24}$

Somewhat more informative are the IR spectra of the thiocyanate and cyanide complexes $\mathbf{2}$ and $\mathbf{4}$ : the well defined absorption found at $c a .2110 \mathrm{~cm}^{-1}$ and the weaker one at $c a .2176 \mathrm{~cm}^{-1}$ are typical of monodentate $S-\mathrm{CN}^{33}$ and $C \mathrm{~N}^{34}$ coordination modes respectively.

As for derivative 1, it is generally accepted that it is possible to distinguish between ionic, monodentate, chelating bidentate or bridging bidentate groups on the basis of $\Delta=v_{\mathrm{a}}(\mathrm{COO})$ $v_{\mathrm{s}}(\mathrm{COO})$ value. On the basis of the observed $\Delta=170 \mathrm{~cm}^{-1}$ value, a chelating bidentate acetate is here predicted. ${ }^{35}$ We have in fact compared the spectrum of $\mathbf{1}$ with that of a number of 
mononuclear $^{36}$ and polynuclear ${ }^{37}$ mercury(II) acetate complexes and found that $\mathbf{1}$ show strict similarity with spectra of $\mathrm{Hg}\left(\mathrm{O}_{2} \mathrm{CCH}_{3}\right)_{2}\left(\mathrm{PR}_{3}\right)_{2}$ species, ${ }^{38}$ containing unsymmetrical chelating carboxylates. Chelating bidentate acetates normally have values of $\Delta$ less than $100 \mathrm{~cm}^{-1},{ }^{39}$ but this seems not applicable in the case of $\mathrm{Hg}\left(\mathrm{O}_{2} \mathrm{CCH}_{3}\right)_{2}$ complexes. In fact, the $\mathrm{Hg}\left(\mathrm{O}_{2} \mathrm{CCH}_{3}\right)_{2}$ itself, for which two coordination has been assigned, has $\Delta$ value of $270 \mathrm{~cm}^{-1}$, very different from the $\Delta$ found for $\mathbf{1}^{40}$

\section{Thermogravimetric Analysis.}

In order to examine the thermal stabilities of the complexes 1-6, thermal gravimetric analyses were carried out between 30 and $500^{\circ} \mathrm{C}$. The TGA curves for compounds 1-6 are supplied as Supplementary Information, Figure S1-S6. Compound 1 is stable up to $144{ }^{\circ} \mathrm{C}$, where it begins to decompose with a first exothermic effect. The observed weight loss (ca. 10.9\%) has been assigned to the evolution of acetic anhydride and to the concomitant formation of a new species which, on the basis of elemental analyses and IR spectroscopy, was formulated as $\left[\mathrm{Hg}_{2}(\mathrm{bim})_{2}\left(\mathrm{CH}_{3} \mathrm{COO}\right)_{2}(\mathrm{O})\right]$. Indeed, the IR spectrum of the residue recovered after controlled heating at $200^{\circ} \mathrm{C}$ exhibits a different absorption pattern in the $1700-1300 \mathrm{~cm}^{-1}$ region, suggesting a significant change in the coordination of the two residual acetates, which, in the heated material, likely act in the chelating or bridging chelating form. The second (complex) step of weight loss begins at ca. $255^{\circ} \mathrm{C}$ and is complete at about $360^{\circ} \mathrm{C}$ : loss of acetic anhydride, sublimation of the organic ligand and $\mathrm{Hg}$, with partial formation of a black residue (carbon), were observed. The thermal behaviour of this compound is completely different from that reported for $\left[\mathrm{Hg}\left(\mu-4,4^{\prime}-\text { bipy }\right)(\mu-\mathrm{AcO})(\mathrm{AcO})\right]_{\mathrm{n}} \cdot \mathrm{n} /{ }_{2} \mathrm{H}_{2} \mathrm{O}$, which shows two exothermic and one endothermic event until to $310^{\circ} \mathrm{C}$, finally forming $\mathrm{HgO}^{[21]}$

The thiocyanate derivative 2 behaves in a different manner: after melting at $c a \cdot 164^{\circ} \mathrm{C}$, it starts to lose weight above $220^{\circ} \mathrm{C}$; at $300^{\circ} \mathrm{C}$ sublimation of the organic ligand is complete. The IR spectrum of the residue recovered after heating at $225^{\circ} \mathrm{C}$ exhibits a signal corresponding to the SCN group, suggesting that at this temperature mercury thiocyanate is not decomposed to $\mathrm{HgS}$. The solid residue formed at around $300^{\circ} \mathrm{C}$ is the ligand-free $\mathrm{Hg}(\mathrm{SCN})_{2}$ which is stable up to $390{ }^{\circ} \mathrm{C}$ and decomposes exothermically at higher temperatures. Species $\mathbf{3}$, the cyanide analogue of $\mathbf{2}$, is stable up to $239^{\circ} \mathrm{C}$, where it starts to release bim and $\mathrm{Hg}$ (up to $340^{\circ} \mathrm{C}$ ).

Interestingly, species $3,\left[\mathrm{Hg}(\mathrm{bim}) \mathrm{I}_{2}\right]_{\mathrm{n}}$, melts at $c a .210^{\circ} \mathrm{C}$, and, at higher temperatures, completely decomposes into bim, molecular iodine and $\mathrm{Hg}$ with a number of exothermic effects. ${ }^{41}$ Slightly more interesting is the thermal behaviour of the chloro-derivatives 5 and $\mathbf{6}$. Indeed, 6 [a $\operatorname{Hg}(\mathrm{I})$ complex] is stable only below $100^{\circ} \mathrm{C}$, where is starts losing $\mathrm{Hg}$ and transforming to $\mathbf{5}$, in agreement with the following disproponation equation: 


\begin{abstract}
Above the transition temperature, the TG spectra of $\mathbf{5}$ and $\mathbf{6}$ are coincident; in particular, melting at ca. $250^{\circ} \mathrm{C}$, followed by release of bim, elimination of the two chlorine atoms(likely as $\mathrm{Cl}_{2}$ ) and then elimination of elemental $\mathrm{Hg}$ is observed. ${ }^{42}$
\end{abstract}

\title{
Structural Analysis.
}

Our XRPD structure determination of 1 revealed the existence of cyclic, centrosymmetric, dimers, crystallizing in the monoclinic $P 2_{1} / n$ space group. In each dimeric molecule (shown in Figure 2), $\mathrm{Hg}$ (II) ions are hexa-coordinated, thanks to the presence of two chelating acetates ( $\mathrm{Hg}-\mathrm{O}$ distances in the 2.22-2.32 $\AA$ range) and two nitrogen atoms from two different bim ligands ( $\mathrm{Hg}-\mathrm{N}$ distances 2.32-2.35 $\AA$ - restrained). The Bim ligand bridges fairly distant $\mathrm{Hg}(\mathrm{II})$ ions, separated by $8.87 \AA$, thanks to the nearly $\mathrm{C}_{\mathrm{s}}$ conformation induced by the two $\mathrm{CH}_{2}$-im torsional angles. This conformation is not rare, as is has been already observed in oligomeric as well as polymeric metal complexes, both of the transition $(\mathrm{Cu}, \mathrm{Zn}, \mathrm{Cd}, \mathrm{Rh})$, or post-transition ( $\mathrm{Sn}$ ) type. Worthy of note, another common conformation, of ideal $\mathrm{C}_{2}$ symmetry, has been observed, and the relative geometric stereochemical preferences estimated on energetic grounds.

Similar cyclic oligomers have been found for zinc (another group 12 metal) and rhodium, ${ }^{43}$ but not for cadmium complexes. ${ }^{21 \mathrm{~b}}$ Moreover, zinc dimers containing halides $(\mathrm{Cl}, \mathrm{Br})$ as ancillary ligands resulted to be very different from the corresponding acetate, ${ }^{21 b}$ which showed a one-dimensional chain topology (thus not crystallizing as discrete entities).

Our structural studies of $\mathbf{2 - 5}$ revealed that all these species contain monodimensional chains determined by the juxtaposition of [-Hg-(bim)-] monomers, with the anionic ligands coordinated to the $\mathrm{Hg}$ (II) ions in a more-or-less ideal tetrahedral fashion. The most relevant geometrical features of the $\mathrm{HgN}_{2} \mathrm{X}_{2}$ chromophores are collected in Table 2, together with some ancillary stereochemical information. Schematic drawings of the infinite chains present in the $\left[\mathrm{Hg}(\mathrm{bim}) \mathrm{X}_{2}\right]_{\mathrm{n}}$ species are shown in Figure 3a-d.

Despite sharing a similar shape and conformation [the bim ligand is nearly - or exactly in 4 and 5 $\mathrm{C}_{\mathrm{s}}$ ], several differences must be highlighted, both at the local coordination sphere of $\mathrm{Hg}(\mathrm{II})$ and at a supramolecular level. The dicyanide species 3 manifests the largest deviation from a tetrahedral coordination, with a $(\mathrm{NC}) \mathrm{Hg}(\mathrm{CN})$ bond angle $\left(>160^{\circ}\right)$ approaching linearity. A similar coordination was found in mercury(II) bispyrazolate, with nearly linear $\mathrm{N}-\mathrm{Hg}-\mathrm{N}$ coordination and two significantly longer contacts in the plane normal to the $\mathrm{N}-\mathrm{Hg}-\mathrm{N}$ vector. ${ }^{44}$ With the caveats imposed 
by the intrinsic low resolution of the method (particularly for the determination of light atoms in the presence of a heavy scatterer), it is however rewarding to see that the $\mathrm{Hg}$-X trend nicely depends on the size of the ligand or of the atom directly bound to the mercuric ion. Moreover, it should be noted that, no matter what the coordination of this ion is (pseudotetrahedral or nearly digonal with ancillary $\mathrm{Hg}-\mathrm{N}$ contacts), $\mathrm{N}-\mathrm{Hg}-\mathrm{N}$ angles fall in a rather narrow range (92 to $97^{\circ}$ ), centred well below the ideal tetrahedral value of $109.5^{\circ}$.

Significant differences can also found at the supramolecular level. This is particularly evident for the diiodide (4) and dichloride (5) couple, which in spite of sharing the same crystal system and space group (the not so common $\mathrm{P} 2_{1} / \mathrm{m}$, one) when viewed down $\mathbf{b}$, as shown in Figure 4 , clearly manifest the different organisation of adjacent chains.

Additionally, also the cyanide and sulfocyanide couple manifest significantly different crystal packings (not shown here), but this is much less surprising, since significant stereochemical differences are already present at the local level (vide supra). Perhaps, the most interesting supramolecular feature of compound $\mathbf{3}$ is the presence of crossed, but not weaved, polymeric chains running along [110] (and its symmetry equivalent direction, [-110]).

\section{Thermodiffractometric Analysis.}

Aiming at studying the dynamic behaviour of these systems, we employed thermodiffractometric techniques to estimate the cell variations on increasing the temperature in "in situ" experiments, using the anisotropic shifts of the diffraction peaks, and to build the corresponding strain tensor. ${ }^{45}$ The numerically extracted results can be schematized as shown in Figure 5a-e, where the relative variations for the cell axes are plotted vs. T. Figure 6a-e, instead, visualizes the thermal strain tensors, derived therefrom, positioned in the unit cell.

As it can be observed in the plots of Figure 5, all cell axes increase with temperature, although at different rates. While this is a common behaviour for intrinsically anisotropic molecular crystals, where most contacts are given by van der Waals interaction, weak and, therefore, very sensible to increased molecular motions (internal degrees of freedom, such as bond distances and angles being typically more rigid), in compounds $\mathbf{2}$ and $\mathbf{5}$ there is one axis (b and $\mathbf{a}$, respectively), which change, 5 to 10 times more than the others. However, simple axis deformations may be misleading when the lattice vectors are not orthogonal. In such cases, it is better to resort to strain tensors as represented by the anisotropic thermal expansion coefficient isosurfaces drawn in green in Figure 6a-e.

The deformation of a crystal by a change in the temperature is expected to be minimal in the direction of the highest atomic density, i.e., the direction of strongest interactions; accordingly, all the polymeric species (but $\mathbf{3}$, vide infra) show small(er) thermal distortion along the chain 


\section{Conclusions.}

Summarizing, we have here presented the complete structural characterization of several novel mercury complexes (one cyclic dimer and one chain polymer) from powder diffraction data, together with some of the material performances derived from thermodiffractometric analysis, linking a structural interpretation with the (apparently incoherent) observed lattice deformation. It is very interesting that, in contrast to other $\mathrm{SCN}, \mathrm{CN}$, and I complexes where the anions acted as bridges over adjactent metal ions (increasing structural dimensionality), in our cases only chain polymers were obtained where the bridging linkers is the $\mathrm{N}_{2}$-donor ligand.

Our thermogravimetric studies demonstrated that in the case of the halide and pseudohalide polymeric complexes the interaction between the $\mathrm{N}_{2}$-ligand and the mercury ion is weak, breaking of the $\mathrm{Hg}-\mathrm{N}$ bonds with dissociation into the starting free ligand and mercury salts being observed in the temperature range $150-230{ }^{\circ} \mathrm{C}$. On the other hand these complexes, although not very stable on heating, were found to be rather resistant to solvent attack (with the notable, though expected, exception of DMSO). Work can be anticipated in the direction of studying the structure versatility of this system, for example by employing different anions or synthetic conditions. 
Acknowledgement. This work was supported by MUR (PRIN2006: "Materiali Ibridi MetalloOrganici Multifunzionali con Leganti Poliazotati”) and Fondazione CARIPLO (Project 2007-5117). We gratefully acknowledge the help of one reviewer, which allowed us to make this paper, in its final version, more easily readable.

Supporting information. Supplementary material contain the TGA traces for compound 1-6, the tables of the lattice parameter evolution as obtained from Le Bail-fits on selected portions of the XRPD trace, and the crystallographic data for compound 1-5. CCDC 720632-720635. These data can be obtained free of charge from The Cambridge Crystallographic Data Centre via www.ccdc.cam.ac.uk/data_request/cif. Supplementary data associated with this article can be found, in the online version, at doi: ***. 
Table 1: Crystal data and refinement details for the compounds 1-5.

\begin{tabular}{|c|c|c|c|c|c|}
\hline $\begin{array}{c}\text { Compound } \\
{\left[\mathrm{Hg}(\mathrm{Bim}) \mathrm{X}_{2}\right]_{\mathrm{n}}}\end{array}$ & $\begin{array}{c}1 \\
\mathrm{CH}_{3} \mathrm{COO}^{-}\end{array}$ & $\begin{array}{c}2 \\
\mathrm{SCN}^{-}\end{array}$ & $\begin{array}{c}3 \\
\mathrm{CN}^{-}\end{array}$ & $\begin{array}{l}4 \\
I^{-}\end{array}$ & $\begin{array}{c}5 \\
\mathrm{Cl}^{-}\end{array}$ \\
\hline Emp. Form. & $\mathrm{C}_{11} \mathrm{H}_{8} \mathrm{Hg}_{2} \mathrm{~N}_{4} \mathrm{O}_{4}$ & $\mathrm{C}_{9} \mathrm{H}_{8} \mathrm{HgN}_{6} \mathrm{~S}_{2}$ & $\mathrm{C}_{9} \mathrm{H}_{8} \mathrm{HgN}_{6}$ & $\mathrm{C}_{7} \mathrm{H}_{8} \mathrm{HgN}_{4} \mathrm{I}_{2}$ & $\mathrm{C}_{7} \mathrm{H}_{8} \mathrm{HgN}_{4} \mathrm{Cl}_{2}$ \\
\hline$f w, \mathrm{~g} \mathrm{~mol}^{-1}$ & 460.80 & 464.94 & 400.79 & 602.56 & 419.66 \\
\hline Crystal system & Monoclinic & Monoclinic & Monoclinic & Monoclinic & Monoclinic \\
\hline SPGR, Z & $\mathrm{P} 2{ }_{1} / \mathrm{n}, 4$ & $\mathrm{P} 2{ }_{1} / \mathrm{c}, 4$ & $\mathrm{C} 2 / \mathrm{c}, 8$ & $\mathrm{P} 2{ }_{1} / \mathrm{m}, 2$ & $\mathrm{P} 2{ }_{1} / \mathrm{m}, 2$ \\
\hline$a, \AA$ & $9.4490(2)$ & $14.2249(3)$ & $14.2670(2)$ & $9.1194(2)$ & $8.3477(2)$ \\
\hline $\mathbf{b}, \AA$ & $15.0057(3)$ & $11.0098(3)$ & $11.9344(1)$ & $9.4293(1)$ & $9.4314(2)$ \\
\hline$c, \AA$ & $10.2300(2)$ & $9.1580(2)$ & $14.8441(2)$ & $8.4101(1)$ & $6.8644(2)$ \\
\hline$\beta, \circ$ & $96.409(2)$ & $110.300(2)$ & $65.787(1)$ & $118.519(1)$ & $90.765(2)$ \\
\hline$V, \AA^{3}$ & $1441.43(5)$ & $1345.19(6)$ & $2305.13(5)$ & $635.43(2)$ & $540.39(2)$ \\
\hline$\rho_{\text {calc }}, \mathrm{g} \mathrm{cm}^{-3}$ & 2.123 & 2.296 & 2.310 & 3.149 & 2.579 \\
\hline$F(000)$ & 856 & 864 & 1472 & 528 & 384 \\
\hline$\mu(\mathrm{Cu}-\mathrm{K} \alpha), \mathrm{cm}^{-1}$ & 193.4 & 233.70 & 251.3 & 596.5 & 298.3 \\
\hline Diffractometer & Bruker D8 & Bruker D8 & Bruker D8 & Bruker D8 & Bruker D8 \\
\hline$T, \mathrm{~K}$ & $298(2)$ & $298(2)$ & $298(2)$ & $298(2)$ & $298(2)$ \\
\hline $2 \theta$ range,$~^{\circ}$ & $5-105$ & $5-105$ & $5-105$ & $5-105$ & $5-105$ \\
\hline Indexing Method & SVD & SVD & SVD & SVD & SVD \\
\hline M/Gof & 68.7 & 23.3 & 28.2 & 71.3 & 76.7 \\
\hline$N_{\text {data }}$ & 5001 & 5001 & 5001 & 5001 & 5001 \\
\hline$N_{o b s}$ & 1666 & 1554 & 1332 & 792 & 617 \\
\hline$R_{p}, R_{w p}^{[a]}$ & $0.072,0.096$ & $0.050,0.067$ & $0.073,0.095$ & $0.045,0.058$ & $0.041,0.053$ \\
\hline$R_{\text {Bragg }}^{[a]}$ & 7.547 & 2.823 & 8.426 & 3.814 & 2.765 \\
\hline$\chi^{2[a]}$ & 16.522 & 5.816 & 15.106 & 7.296 & 7.032 \\
\hline$V / Z, \AA^{3}$ & 360.4 & 336.3 & 288.1 & 317.7 & 270.2 \\
\hline
\end{tabular}

${ }^{[a]} R_{p}=\Sigma_{i}\left|y_{i, o}-y_{i, c}\right| / \Sigma_{i}\left|y_{i, o}\right| ; R_{w p}=\left[\Sigma_{i} w_{i}\left(y_{i, o}-y_{i, c}\right)^{2} / \Sigma_{i} w_{i}\left(y_{i, o}\right)^{2}\right]^{1 / 2} ; R_{B}=\Sigma_{n}\left|I_{n, o}-I_{n, c}\right| / \Sigma_{n} I_{n, o} ; \chi^{2}=\Sigma_{i} w_{i}$ $\left(y_{i, o}-y_{i, c}\right)^{2} /\left(N_{o b s}-N_{p a r}\right)$, where $y_{i, o}$ and $y_{i, c}$ are the observed and calculated profile intensities, respectively, while $I_{n, o}$ and $I_{n, c}$ the observed and calculated intensities. The summations run over $i$ data points or $n$ independent reflections. Statistical weights $w_{i}$ are normally taken as $1 / y_{i, o}$. 
Table 2. Synoptic collection of most relevant geometric parameters ( $\left(\AA\right.$ and ${ }^{\circ}$ ) for compounds 1-5. Starred values have been subjected to soft-restraints.

\begin{tabular}{|c|c|c|c|c|c|c|c|}
\hline Compound & $H g \cdots H g$ & $H g-N$ & $N-H g-N$ & $H g-X$ & $X-H g-X$ & $\begin{array}{c}\text { Bim } \\
\text { symmetry }\end{array}$ & $\begin{array}{c}\text { I-D chain } \\
\text { // to }\end{array}$ \\
\hline 1 & 8.87 & $2.32-2.35^{*}$ & 91.9 & $\begin{array}{c}2.22-2.24 \\
2.30-2.32\end{array}$ & - & $C_{s}$ & \\
\hline 2 & 9.16 & $2.37^{*}$ & 91.7 & $2.42-2.43$ & 135.3 & $C_{s}$ & {$[001]$} \\
\hline 3 & 9.30 & 2.40 & 96.1 & $2.05^{*}$ & 161.1 & $C_{s}$ & {$[110]$} \\
\hline 4 & 9.43 & 2.38 & 92.3 & $2.67-2.70$ & 128.9 & $C_{s}$ & {$[010]$} \\
\hline 5 & 9.43 & 2.36 & 96.5 & $2.39-2.42$ & 115.9 & $C_{s}$ & {$[010]$} \\
\hline
\end{tabular}



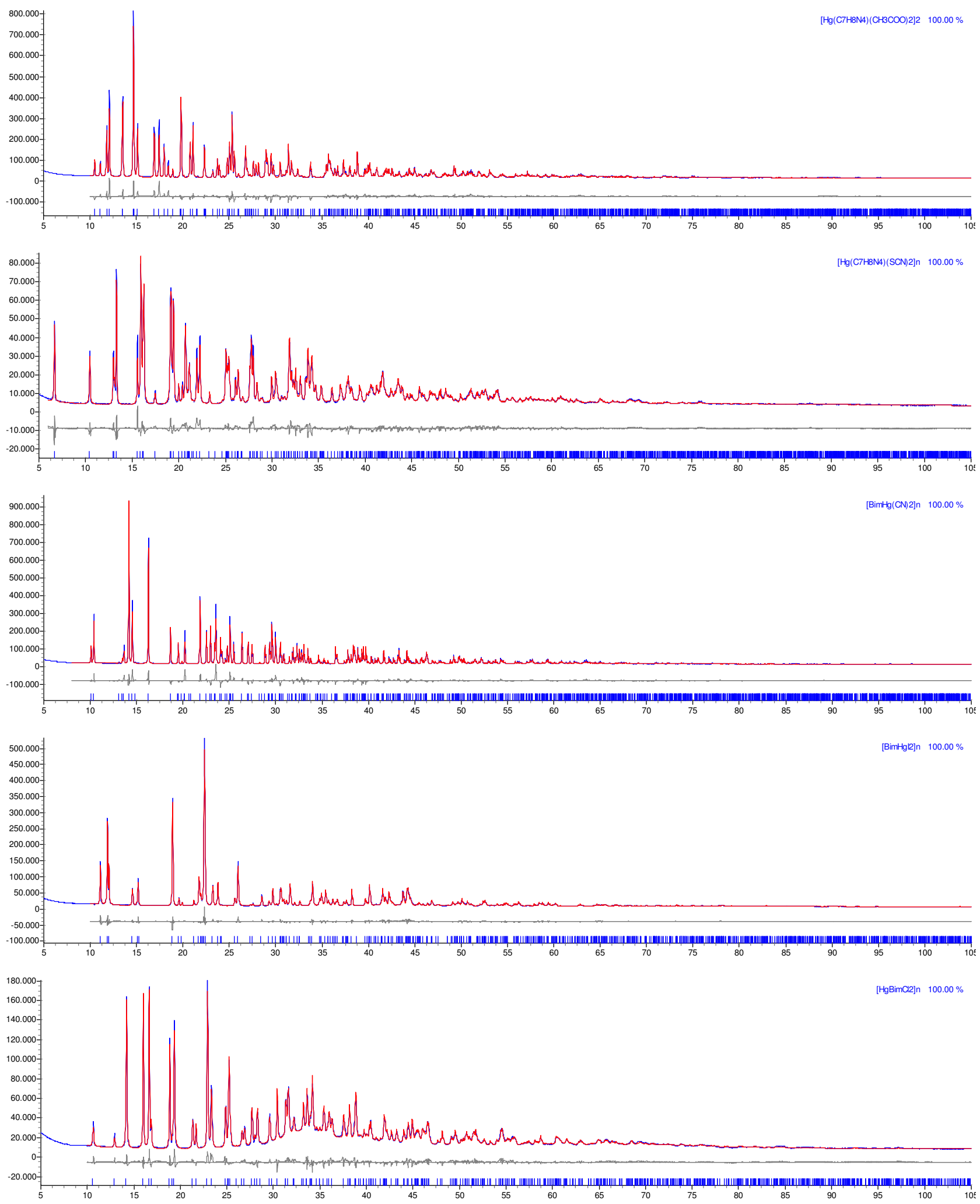

Figure 1. Rietveld refinement plots for compounds 1-5 with peak markers and difference plots at the bottom. 


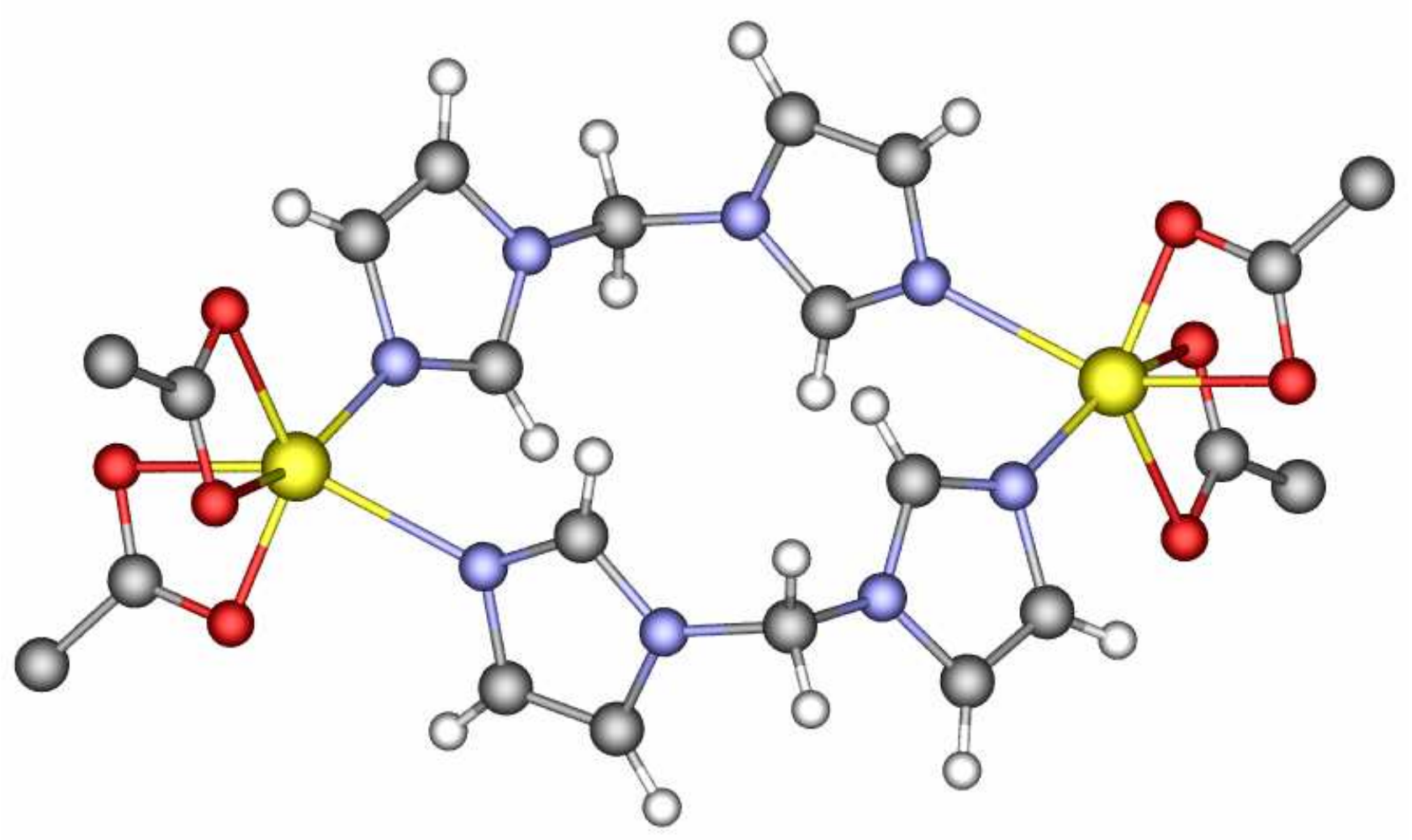

Figure 2. Schematic drawing of the structure of the $\left[\mathrm{Hg}(\mathrm{bim})\left(\mathrm{CH}_{3} \mathrm{COO}\right)_{2}\right]_{2} \mathbf{1}$ molecule, as derived by our powder diffraction analysis. 


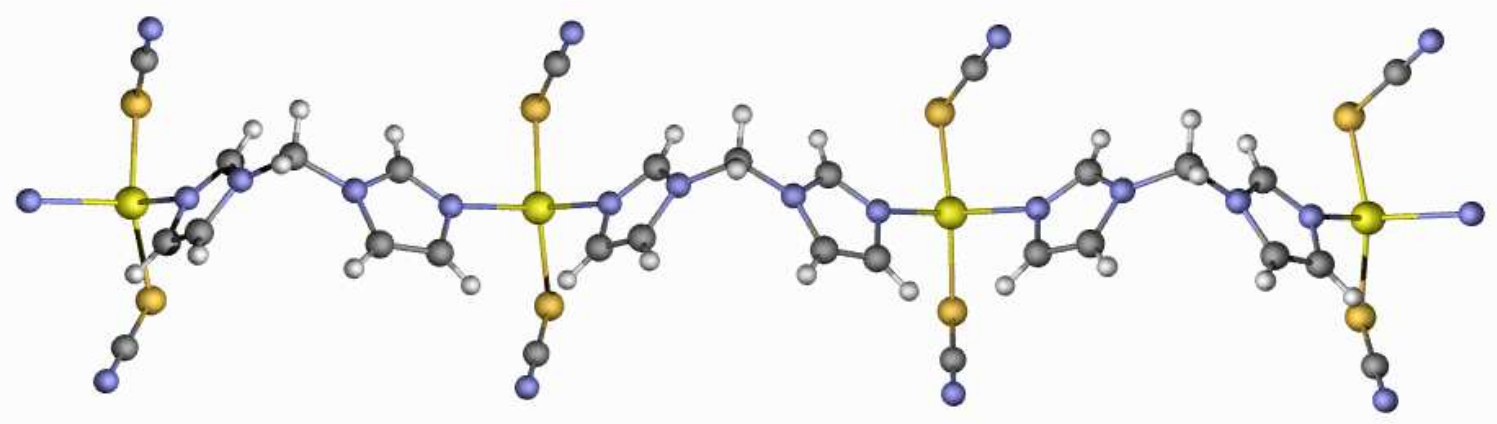

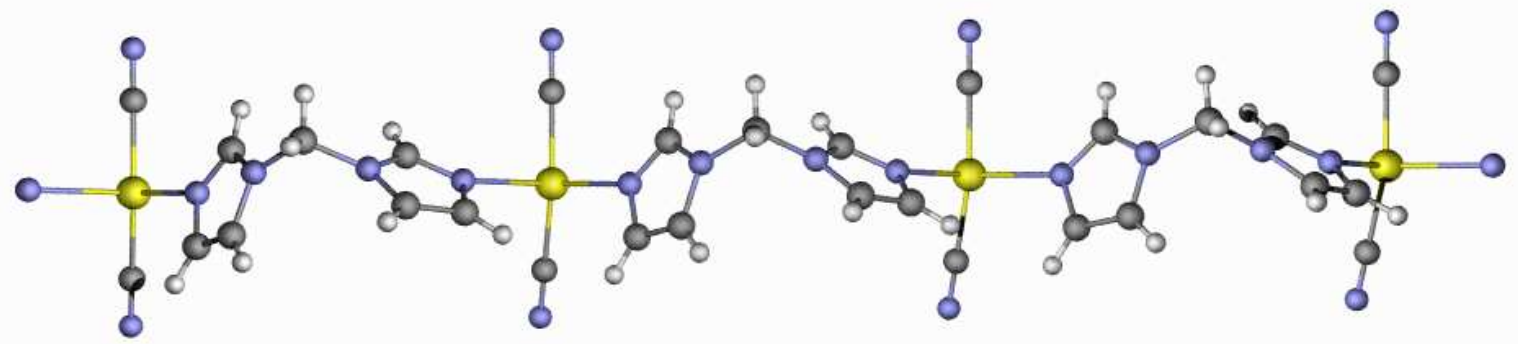

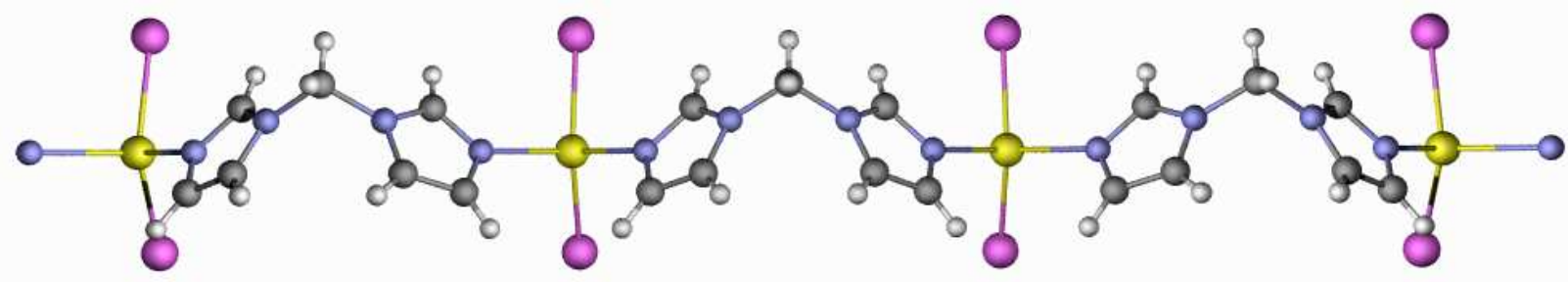

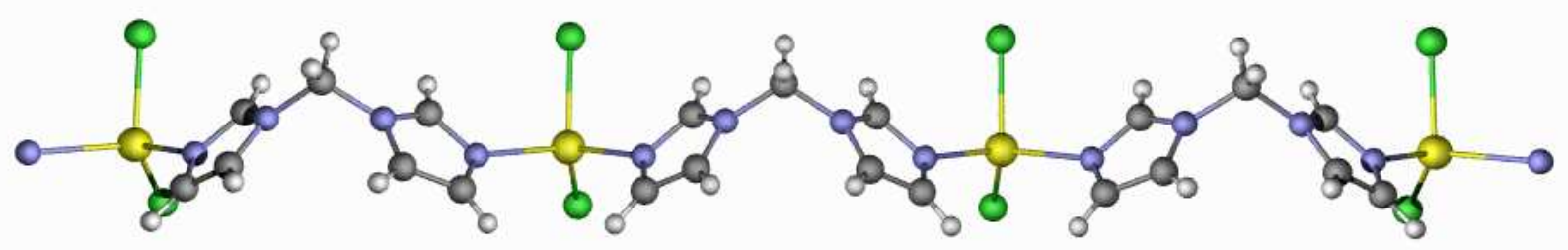

Figure 3. Schematic drawing of the structures of the $\left[\mathrm{Hg}\left(\mathrm{C}_{7} \mathrm{H}_{8} \mathrm{~N}_{4}\right)(\mathrm{SCN})_{2}\right]_{\mathrm{n}} \mathbf{2},\left[\mathrm{Hg}\left(\mathrm{C}_{7} \mathrm{H}_{8} \mathrm{~N}_{4}\right)(\mathrm{CN})_{2}\right]_{\mathrm{n}}$ 3, $\left[\mathrm{Hg}\left(\mathrm{C}_{7} \mathrm{H}_{8} \mathrm{~N}_{4}\right) \mathrm{I}_{2}\right]_{\mathrm{n}} 4$ and $\left[\mathrm{Hg}\left(\mathrm{C}_{7} \mathrm{H}_{8} \mathrm{~N}_{4}\right) \mathrm{Cl}_{2}\right]_{\mathrm{n}} \mathbf{5}$ molecules (top to bottom), as derived by our powder diffraction analysis. 

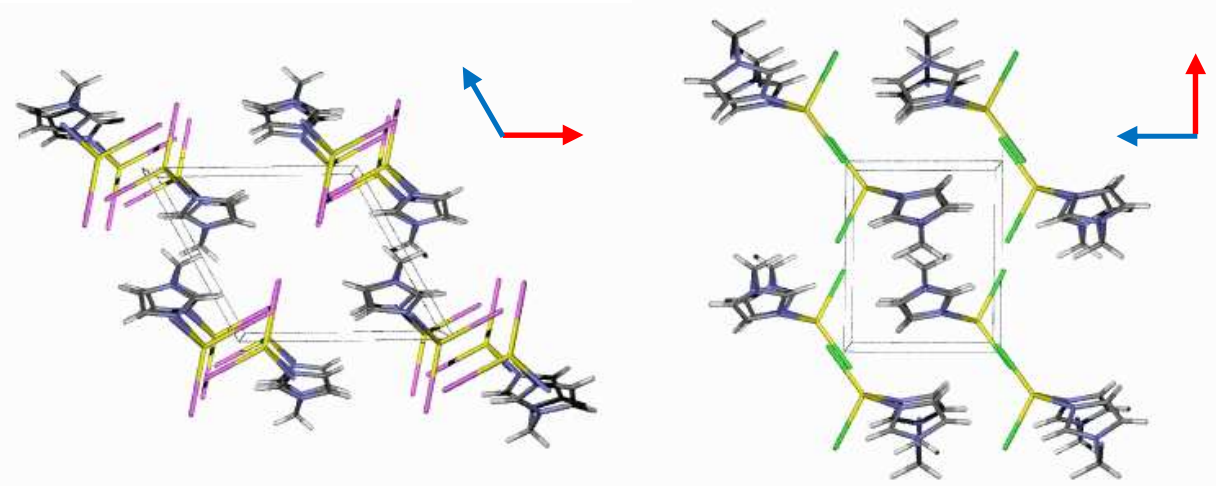

Figure 4. Schematic drawing of the crystal packing of $\left[\mathrm{Hg}\left(\mathrm{C}_{7} \mathrm{H}_{8} \mathrm{~N}_{4}\right) \mathrm{I}_{2}\right]_{\mathrm{n}} 4$ and $\left[\mathrm{Hg}\left(\mathrm{C}_{7} \mathrm{H}_{8} \mathrm{~N}_{4}\right) \mathrm{Cl}_{2}\right]_{\mathrm{n}} 5$ highlighting their non-isomorphic character (see text) - $a$ axis in red, $c$ axis in blue. 


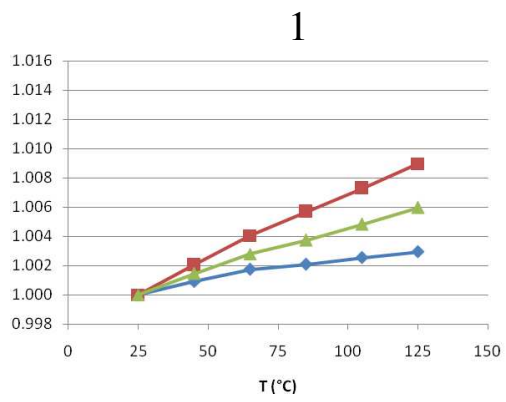

3

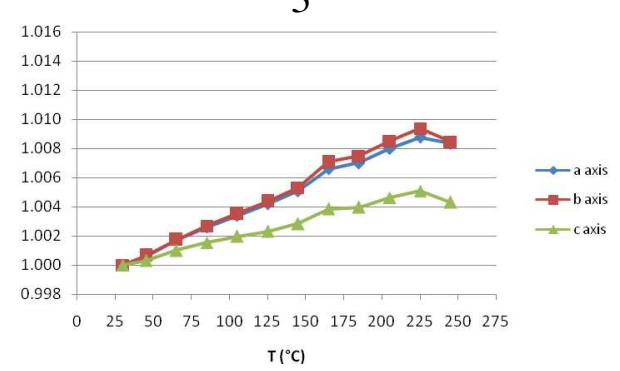

5

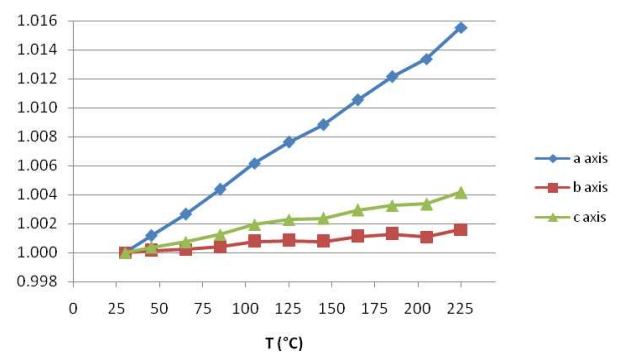

2

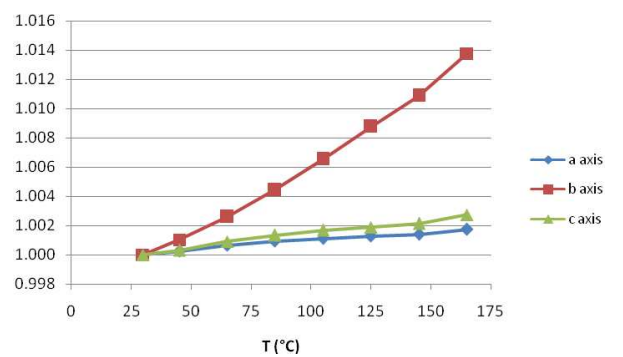

4

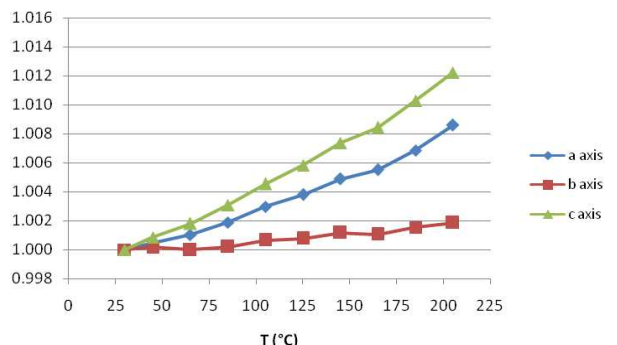

Figure 5. Temperature evolution of the lattice parameters of compounds 1-5, normalized to their r.t. values. 


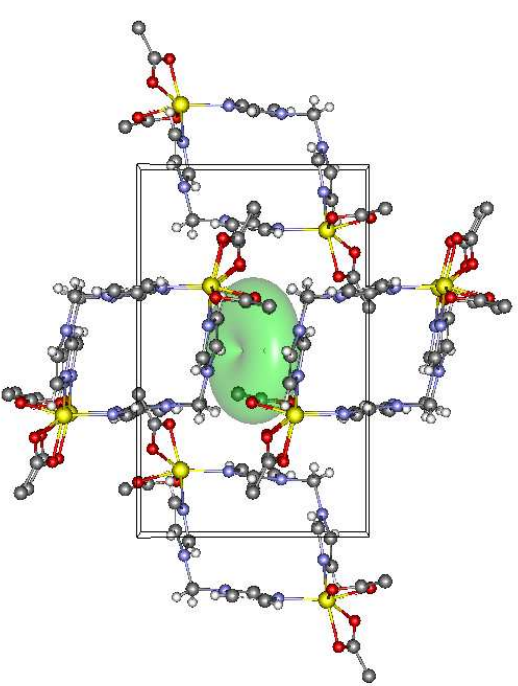

1

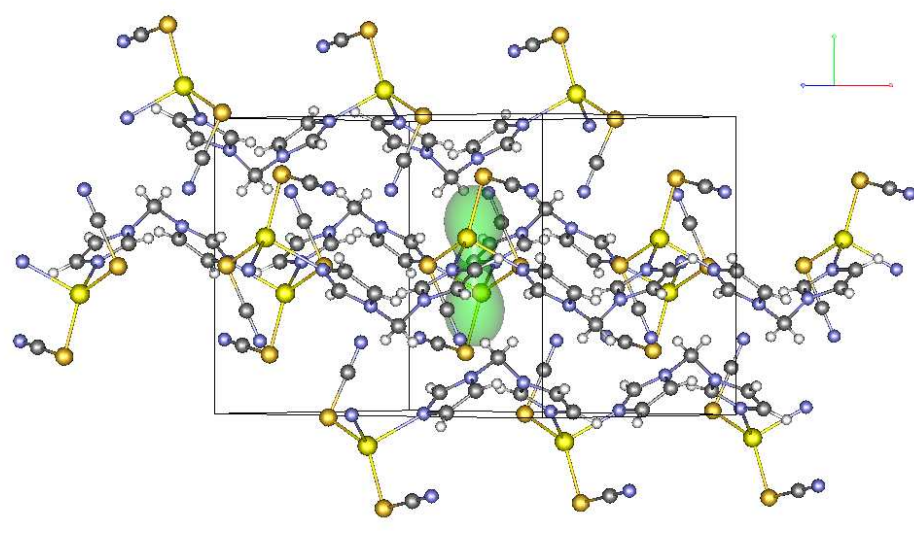

2

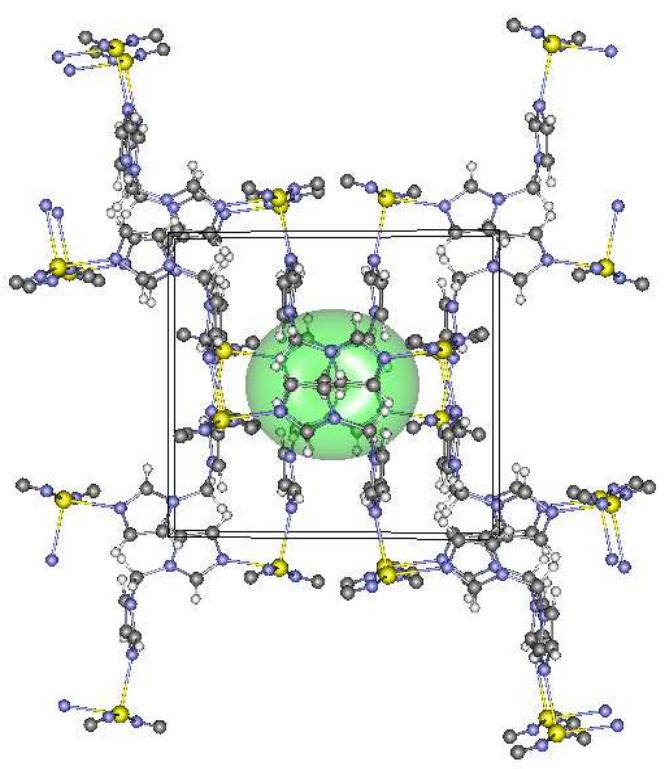

3

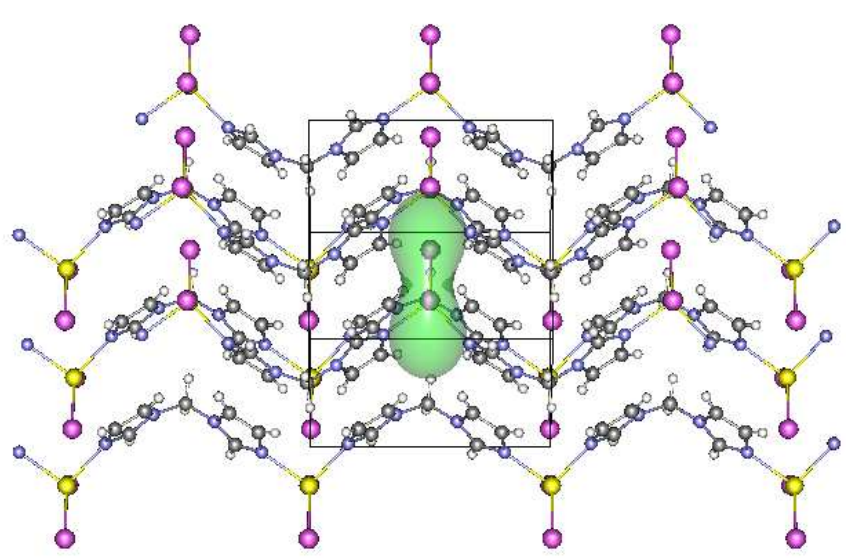

4

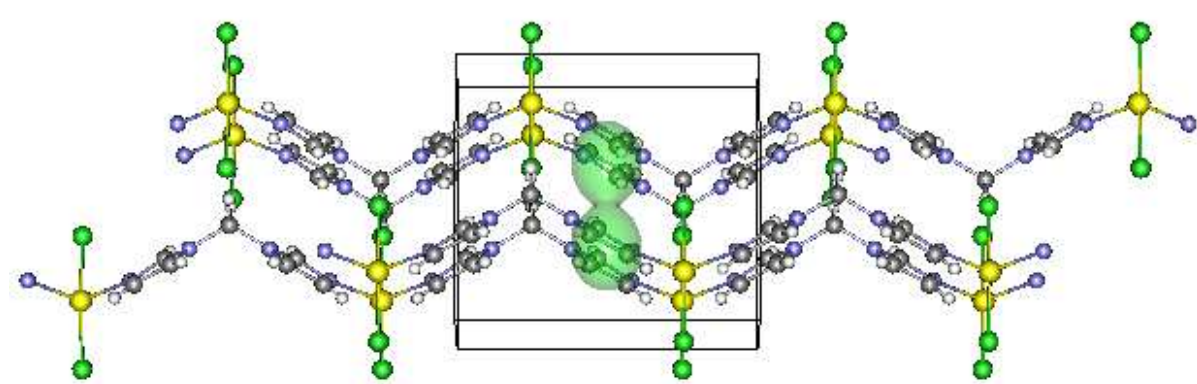

5

Figure 6. Thermal expansion coefficients isosurfaces (thermal strain tensors) drawn within the crystal structure of compounds 1 (along $c, a$ from left to right, $b$ from bottom to top), $\mathbf{2}$ (the same orientation of $\mathbf{1}$ ), $\mathbf{3}$ (the same orientation of $\mathbf{1}$ ), $\mathbf{4}$ (along $b, a$ from left to right, $c$ from top to bottom) and $\mathbf{5}$ (along $b, a$ from left to right and $c$ from bottom to top). 


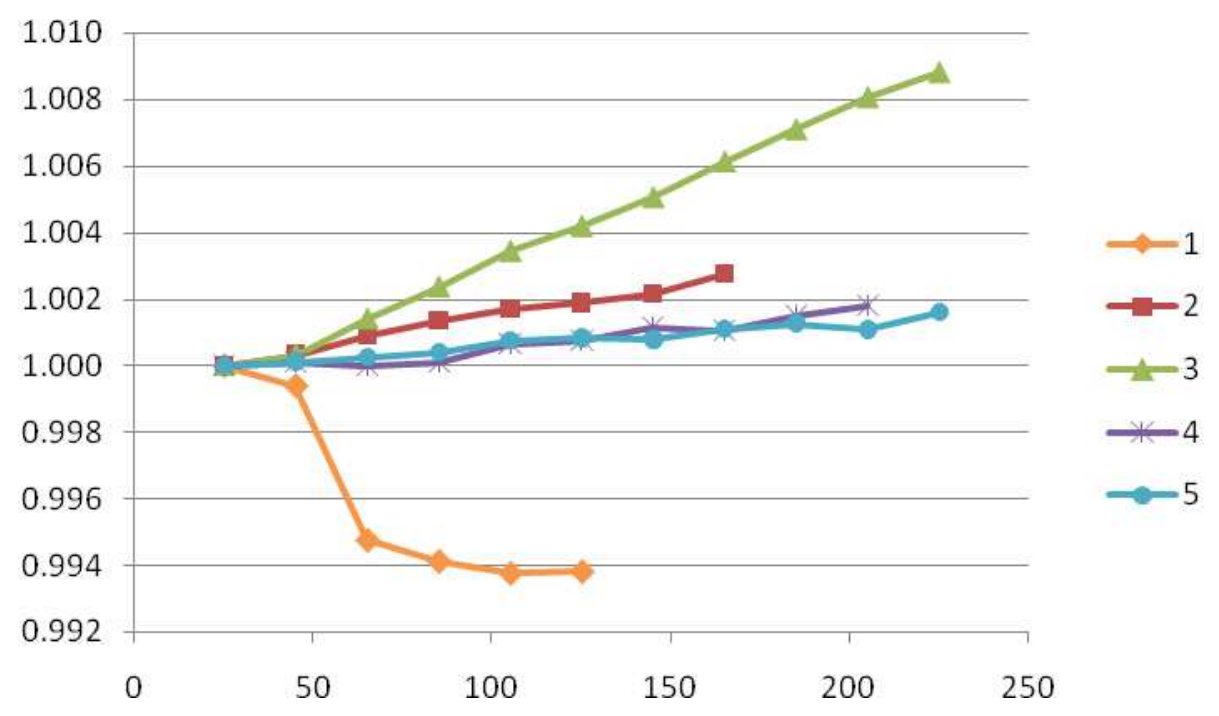

Figure 7. Temperature evolution of the intramolecular $\mathrm{Hg} \cdots \mathrm{Hg}$ distance in polymers 1-5. 


\title{
For the Table of Contents
}

\begin{abstract}
Several polynuclear $\mathrm{Hg}$ (II) complexes containing the flexible ditopic bisimidazolylmethane ligand bim ligand have been prepared and their crystal structures retrieved from laboratory powder diffraction data. Using thermodiffractometric methods, the thermal expansion coefficients and the related strain tensors were also determined.
\end{abstract}

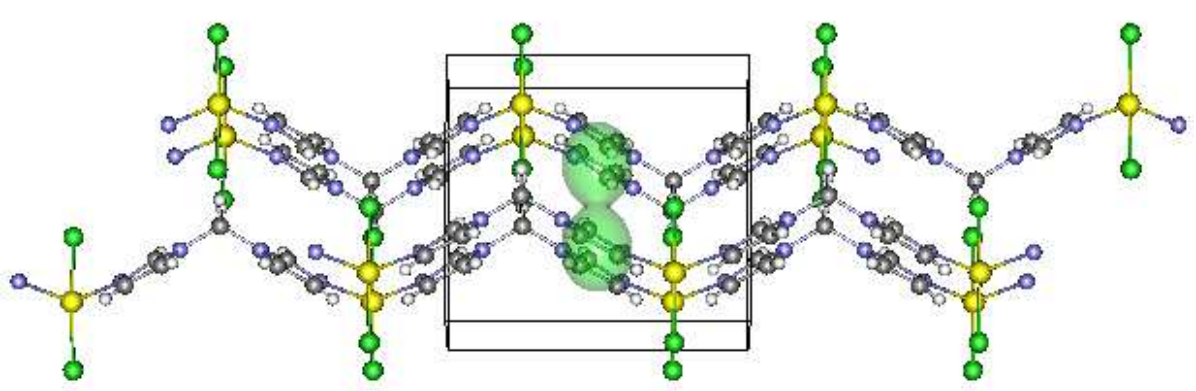




\section{References}

${ }^{1}$ See for example: Cingolani, A.; Galli, S.; Masciocchi, N.; Pandolfo, L.; Pettinari, C.; Sironi, A.; J. Am. Chem. Soc., 2005, 127, 6144-6145 and references therein.

${ }^{2}$ See for example: Masciocchi, N.; Bruni, S.; Cariati, E.; Cariati, F.; Galli, S.; Sironi, A.; Inorg. Chem., 2001, 40, 5897

${ }^{3}$ See for example: Navarro, J.A.R.; Barea, E.; Rodriguez Dieguez, A.; Salas, J.M.; Ania, C.O.; Parra, J.B.; Masciocchi, N.; Galli, S.; Sironi, A.; J. Am. Chem. Soc., 2008, 130, 3978-3984 and references therein:

${ }^{4}$ Casellas, H.; Gamez, P.; Reedijk, J.; Mutikainen, I.; Turpeinen, U.; Masciocchi, N.; Galli, S.; Sironi, A.; Inorg. Chem., 2004, 44, 7918-7924.

${ }^{5}$ Casellas, H.; Roubeau, O.; Teat, S.J., Masciocchi, N., Galli, S.; Sironi, A.; Gamez, P.; Reedijk, J.; Inorg. Chem., 2007, 46, 4583-4591.

6 Pettinari, C.; "Scorpionates II: The chelating borate ligands", 2008, Imperial College Press, London, UK.

${ }^{7}$ Galli, S.; Masciocchi, N.; Cariati, E.; Sironi, A.; Barea, E.; Haj, M.A.; Navarro, J.A.R.; Salas, J.M.; Chem. Mater, 2005, 17, 4815-4824.

${ }^{8}$ Ardizzoia, G.A.; Cenini, S.; La Monica, G.; Masciocchi, N.; Moret, M.; Inorg. Chem., 1994, 33. 1458-1463.

${ }^{9}$ Galli, S., Masciocchi, N., Tagliabue, G.; Sironi, A.; Navarro, J.A.R.; Salas, J.M.; Mendez-Liñan, L.; Domingo, M.; Perez-Mendoza, M.; Barea, E.; Chemistry Eur. J., 2008, 14, 9890-9901.

${ }^{10}$ Masciocchi, N.; Galli, S.; Alberti, E.; Sironi, A.; Di Nicola, C.; Pettinari, C.; Pandolfo, L. Inorg. Chem. 2006, 45, 9064-9074.

${ }^{11}$ (a) Claramunt, R. M.; Elguero, J.; Meco, T. J. Heter. Chem. 1983, 20, 1245-1249; (b) Li, J. Acta Cryst. 2006, E62, o1798-o1799.

12 Tabushi, I.; Sasaki, T. J. Am. Chem. Soc., 1983, 105, 2901-2902.

${ }^{13}$ In, S.; Kang J. J. Incl. Phen. Macr. Chem. 2006, 54, 129-132.

${ }^{14}$ Jin, C.-M.; Lu, H.; Wu, L.-Y.; Huang, J. Chem. Commun. 2006, 5039-5041.

15 Jin, S.; Chen, W. Inorg. Chim. Acta 2007, 360, 3756-3764.

${ }^{16}$ Jin, S.; Chen, W.; Qiu, H. Cryst. Growth Des. 2007, 7, 2071-2079.

${ }^{17}$ Jin S.; Wang, D.; Chen, W. Inorg. Chem. Commun. 2007, 10, 685-689.

${ }^{18}$ Jin, S.-W.; Chen, W.-Z. Polyhedron 2007, 26, 3074-3084.

${ }^{19}$ Hwang, I-C.; Chandran, R. P.; Singh, N. J.; Khandelwal, M.; Thangadurai, T. D.; Lee, J.-W.; Chang, J. A.; Kim, K. S. Inorg. Chem., 2006, 45, 8062-8069. 


\footnotetext{
${ }^{20}$ Wang, X.-F.; Yang, L.; Okamura, T.-a., Kawaguchi, H.; Wu, G.; Sun, W.-Y.; Ueyama, N. Cryst. Growth Des., 2007, 7, 1125-1133.
}

${ }^{21}$ a) Masciocchi, N.; Pettinari, C.; Alberti, E.; Pettinari, R.; Di Nicola, C.; Figini Albisetti, A.; Sironi, A.; Inorg. Chem., 2007, 46. 10491-10500, b) ibid. 2007, 46, 10501-10509.

${ }^{22}$ Lorenzotti, A.; Cecchi, P.; Pettinari, C.; Leonesi, D.; Bonati, F. Gazz. Chim. Ital. 1991, 121, 8991.

${ }^{23}$ Pettinari, C.; Marchetti, F.; Lorenzotti, A.; Gioia Lobbia, G.; Leonesi, D.; Cingolani, A. Gazz. Chim. Ital. 1994, 124, 51-55.

${ }^{24}$ Pettinari, C.; Santini, C.; Leonesi, D.; Cecchi, P. Polyhedron 1994, 13, 1553-1562.

${ }^{25}$ Version 3.0, Bruker AXS, 2005, Karlsruhe, Germany.

26 Acentric $C c$, a proper subgroup of $C 2 / c$, was also considered as a possible candidate. The complexity of the structure of species 3 within such a description (requiring the introduction of stiff restraints in order to reach convergence to a chemically significant model) and the absence of a cristallochemical clue (suggesting that a centrosymmetric structure is not tolerable), together with the presence of a dominating scatterer (the $\mathrm{Hg}$ ion) makes it impossible to assess. from powder data only, the significance of the agreement factor lowering observed upon doubling the number of free structural parameters, therefore, the centric model was eventually adopted, which we believe consistent with all chemical and crystallographic data in our hands.

27 For compounds 1, 2 and 3, the cartesian coordinates of bim derived from literature data were used (CCDC code: EZESEH), optimized by molecular mechanics, using Tinker (http://dasher.wustl.edu/tinker/). In species 4 and 5, where the bim ligand is bisected by mirror planes, we adopted the z-matrix formalism, defining regular pentagons (C-X $1.343 \AA$, C-H $0.950 \AA$ ) for the heterocyclic ring (with their correct atomic species), hinged about a methylene bridge $\left(\mathrm{CH}_{2}\right.$ N $1.457 \AA$ ) of idealized tetradedral geometry.

${ }^{28}$ Stinton, G. W., Evans, J. S. O. J.Appl.Crystallogr. 2007, 40, 87-95.

${ }^{29}$ Ohashi, Y. in "Comparative Crystal Chemistry", R.M.Hazen and L.W. Finger Eds., 1982, Wiley, NY, pp. 92-102.

30 Kaminsky, W., "Wintensor: Tensor-drawing and calculation tool for Windows 95/98/NT/2000/XP”, University of Washington, Seattle, USA.

${ }^{31}$ ref. Jain, S.C.; Rivest, R. Inorg. Chim. Acta 1969, 3, 552-558; James, B. R.; Morris, R. H. Spectrochim. Acta A: 1978, 34A, 577-582.

${ }^{32}$ ref. Niu, Y.; Guo, X.; Liu, X.; Wang, Q.; Zhang, N.; Zhu, Y.; Hou, H.; Fan, Y. J. Chem. Crystallogr. 2006, 36, 643-646.

${ }^{33}$ Mahmoudi, G.; Morsali, A.; Zhu, L. G. Polyhedron 2007, 26, 2885-2893. 
${ }^{34}$ Goel, R. G.; Henry W. P.; Ogini, W. O. Can. J. Chem. 1979, 57, 762-766.

${ }^{35}$ Mahmoudi, G.; Morsali, A.; Hunter, A. D.; Zeller, M. Inorg. Chim. Acta 2007, 360, 3196-3202.

${ }^{36}$ Roberts, P. J.; Ferguson G.; Goel, R. G.; Ogini, W. O.; Restivo, R. J. J. Chem. Soc. Dalton Trans. 1978, 253-256.

${ }^{37}$ Morsali A.; Zhu, L.-G. Helv. Chim. Acta 2006, 89, 81-93.

${ }^{38}$ Alyea, E. C.; Dias, S. A. Can. J. Chem. 1979, 57, 83-90.

${ }^{39}$ Alcock, N. W.; Tracy, V. M.; Waddington, T. C. J. Chem. Soc. Dalton Trans. 1976, 2243-2246.

${ }^{40}$ Cooney, R. P. J.; Hall, J. R. J. Inorg. Nucl. Chem. 1972, 34, 1519.

${ }^{41}$ Mahmoudi, G.; Morsali, A.; Zeller, M. Solid State Sciences 2008, 10, 283-290.

42 Popović Z; Soldin Ž; Pavlović, G.; Matković-Čalogović, D.; Mrvoš-Sermek, D.; Rajić, M. Structural Chemistry 2002, 13, 425-436.

${ }^{43}$ Masciocchi, N.; Figini Albisetti, A.; Sironi, A.; Pettinari, C.; Marinelli, A.; Powder Diffraction, 2007, 22, 236-240.

${ }^{44}$ Masciocchi, N.; Ardizzoia, G.A.; La Monica, G.; Maspero, A.; Sironi, A. Inorg. Chem., 1999, 38, 3657-3664.

${ }^{45}$ Zotov, N. Acta Crystallogr, 1990, A46, 627-628. 